\title{
JURNAL SENI MUSIK
}

\section{Analysis Of Form And Presentation On The Song "Bingung" By Iksan Skuter}

\author{
Lingga Nusantara Putra ${ }^{\square 1}$ \\ Universitas Negeri Semarang, Indonesia \\ Mochammad Usman Wafa \\ Universitas Negeri Semarang, Indonesia
}

Article Info

Submitted : August, 2021

Revised : November,2021

Accepted:December,2021

\section{Keywords:}

Music Form, Iksan Skuter,

Song"Bingung",

\section{Abstract}

Iksan Skuter is a musician who likes to voice songs with the theme of social criticism. In this paper, the writer focuses on one song by Iksan Skuter, namely the song titled Bingung. The song Bingung contains a social critique of contradictions that have always been a concern of the people in Indonesia. The reason why the writer made the song Bingung by Iksan Skuter the focus of the research is that according to the writer this song has simplicity in the form of music, has a series of melodies that are easy to remember, has straightforward lyrics, and this song is quite in demand by the public, this can be seen from the following: the number of individuals and groups who re-sung this song. The research method used was descriptive qualitative with a content analysis approach. Data collection techniques include: observation, interview, and documentation techniques.

The results showed that the song Bingung consisted of three parts, namely part A, part B, and part $\mathrm{C}$ with sentence structures or musical phrases part A (a, x), B (b, b1) and C (c, z). 


\section{INTRODUCTION}

Humans are civilized and cultured creatures, and because of these two things, humans can be said to be the most perfect creatures of God. Kontjoroningrat also once said that there are seven elements of culture itself, of which the seven universal elements are 1) religious systems and religious ceremonies, 2) social systems and organizations, 3) knowledge systems, 4) language, 5) arts, and so on. ) livelihood systems, 7) technology and equipment systems. (Koentjaraningrat, 1981:5)

Art is an expression of the artist's feelings conveyed to others so that they can feel what he feels. The types of feelings that the artist expresses vary. There is a strong, weak feeling; feeling important, meaningless; good bad feelings. Even feelings of joy, admiration, peace, love for the country, and so on. All feelings received by the human senses provide an artistic experience (Iswantara, 2016: 29).

Music is a form of art work in the form of sound in the form of songs or musical compositions that express the thoughts and feelings of the creator which is poured through musical elements, namely rhythmic melody, harmony, form and structure of songs and expressions so that they become a single unit (Jamalus, 1988: 1). 1). Music is an engineering that is completely formed by intention. Not because of coincidence, although these factors are more or less often influential (Hardjana, 2003:).

Song is a type of music that has a very important function of non-musical elements that give a certain impression to the music, namely song lyrics. The lyrics of the song in the form of language give a new dimension to the song itself. The impression of majesty, majesty, joy, sadness, and others. is the effect that is caused when the song is sung or listened to by Suharto (2006). Song lyrics are the result of an author's interpretation in viewing a phenomenon that occurred at that time. This phenomenon is not only understood as an understanding of the sociology of its people, but other things that are more abstract; for example in terms of psychological aspects and ideas of thought, even the dynamics of the definitive meaning of music from time to time can be used as a reference for subsequent literary works. Song lyric works that can be said to be good are always relative; a cohesive relationship between the author's object of observation and the reader's taste in interpreting the work (Ricoeur, 2006:14)

According to Walzer (2002:3), social criticism is a social activity that is the same age as the community itself. Social criticism as an action or social activity is an activity to compare and observe carefully and see developments carefully about the good or bad quality of a society that can be done by anyone. Social criticism is an activity related to judging, comparing, and revealing the social conditions of a society related to the values adopted.

Iksan Skuter is a musician who creates many songs with the theme of politics, the environment, and nature. One of his songs is a song entitled Bingung which is the focus of this research. The song Bingung itself has two versions, the first version or the original version and the second version or the acoustic version, in this study the author focuses on the research on the second version of the song or the acoustic version. The reason the author chose the second version of the song or the acoustic version is because Iksan Skuter often appears in performances using this version. In the acoustic version, Iksan Skuter presents music in the form of a combination of instruments and vocals, which he uses as an accompaniment medium for vocals.

The song Bingung contains a social critique of contradictions that have always been a concern of the people in Indonesia. The reason why the writer made the song Bingung by Iksan Skuter the focus of the research is that according to the author this song has simplicity in the form of music, has a series of melodies that are easy to hear and 
remember, has straightforward lyrics, and this song is quite in demand by the public, this can be seen From the number of individuals and groups who sing this song, whether it's in a meeting or deliberately resing it and then uploading it to a digital platform such as YouTube, the number of people who listen to this song can also be seen from the number of impressions of this song on the YouTube (Iksan Scooter Official) channel.

\section{METHOD}

This research is descriptive in nature, has the aim of knowing, analyzing, and describing the form of the song Confused by Iksan Skuter. Meanwhile, based on the source of the data and the characteristics of the data that will be studied in this study in order to explore the data needed by the researcher is a qualitative descriptive method.

The object of this research is Iksan Scooter, located at Havana Coffee, having its address at Jalan Letjen Sutoyo, Malang, East Java. Data collection techniques are observation, documentation, and interviews. Margono (2003: 158), observation is surveillance and recording systematically to the symptoms appeared on the object of this research. Data validity techniques. Data analysis in this research is descriptive qualitative, namely analysis in the form of statements and analysis expressed by description.

Conducting observations by visiting informants at the research location, interviews with cooperative informants, and document studies, namely checking documentation in the form of hard files and soft files and perpetuating any data needed to complete the research in the form of photos, audio, letter documents and scores, and videos. Next is the data validity technique using triangulation of sources and data. Researchers get data from existing sources and then combine and conclude which data is important to analyze and use to describe research results so that the data is more accurate.

\section{RESULTS AND DISCUSSIONS}

Through song lyrics, the songwriter tries to convey his aesthetic ideas. This is because the lyrics of the song are written in such a way that the listener feels entertained and tries to understand the content of the song. In addition, lyrics can also function as a medium of information. This means that song lyrics provide information to the public or listeners about a problem.

Song Bingung is a work of Iksan Skuter. The Bingung Song is a song that consists of three parts. According to SJ, $(1996: 12)$ the form of a three-part song is a song with a different sentence or period. Sharpened by Muttaqin, (2008: 136) that is, if the form of a two-part song has an A-B pattern, then the three-part pattern is A-BA. The third part is not merely repetition but can be with changes. This form has patterns in various sizes which include: three part, initial three part song form, three part song form, extended three part song form, five part song form.

After analyzing the data that has been obtained, the researcher got some facts about the form of the song Bingung. The song Bingung consists of three parts, namely part $\mathrm{A}$, part $\mathrm{B}$, and part $\mathrm{C}$ with musical words or phrases part $\mathrm{A}(\mathrm{a}, \mathrm{x})$, part $\mathrm{B}(\mathrm{b}, \mathrm{b} 1)$, and part $\mathrm{C}(\mathrm{c}, \mathrm{z})$. the following is a picture of the musical score of the song Bingung in each part and the sentence in each part. This sentence is in the form of analysis of motifs and division of phrases. 
1. Motif and Phrase part A

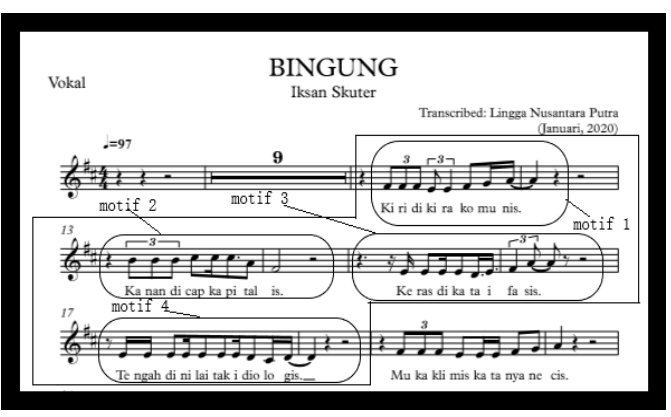

Figure 1. Motif part A

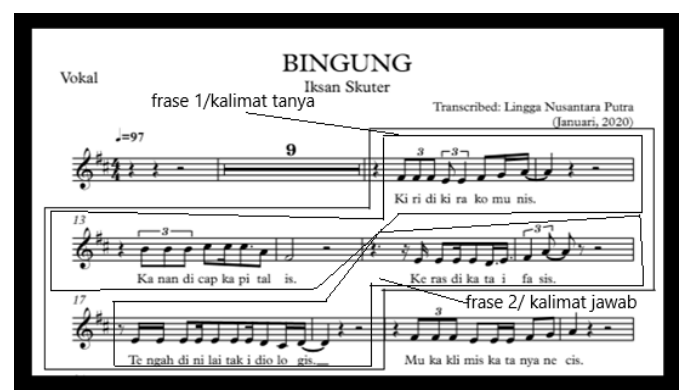

Figure 2. Phrase part A

From the notation above, it can be explained that the first part of the song Bingung starts from bar 11 to bar 41, with a total of 30 bars. The phrase (a) is found on measures 11 to 14 , starting on the second beat on bar 11 to the first beat on bar 14 . The phrase (x) is found on measures 15 to 17.

\section{Motif and Phrase Part B}

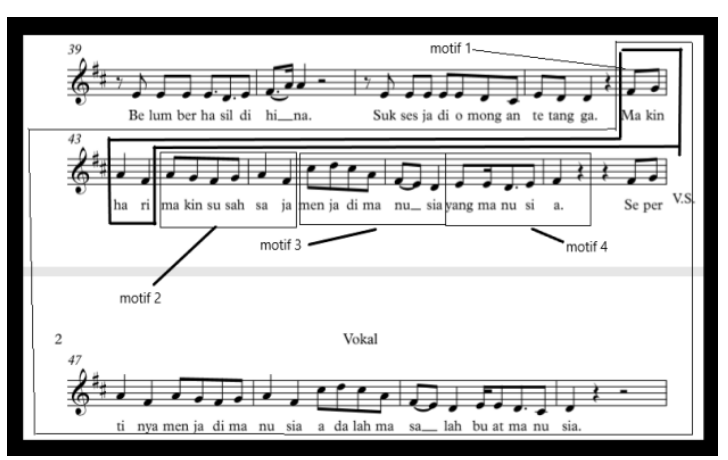

Figure 3. Motif part B

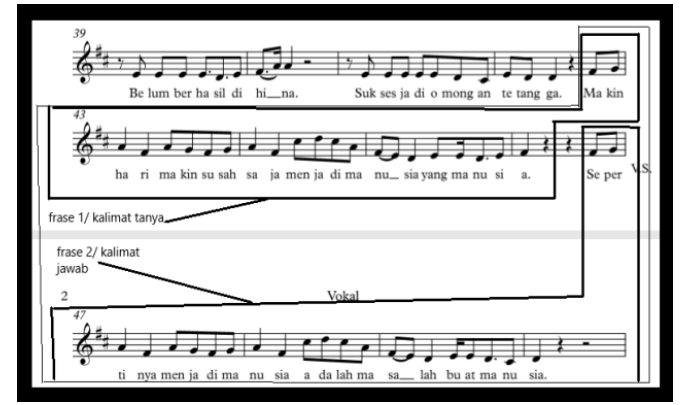

Figure 4. Phrase part $\mathrm{B}$

From the notation above, it can be explained that the first motif (m1) in the second part starts at bar 42 in the fourth beat to bar 43 in the second beat, the second motif (m2) in the second part of this song is located at bar 43 in the third beat to bar 44 in the second beat. the second beat, the third motif (m3) is found on bar 44 in the third beat to bar 45 in the second beat, and the fourth motif (m4) is found on bar 45 in the third beat to bar 46 in the first beat. The phrase (b) in this second part is located at measure 42 in the fourth beat to bar 46 in the first beat, while the phrase (b1) is located at bar 46 in the fourth beat to bar 50 in the first beat.

\section{Motif and Phrase Part C}

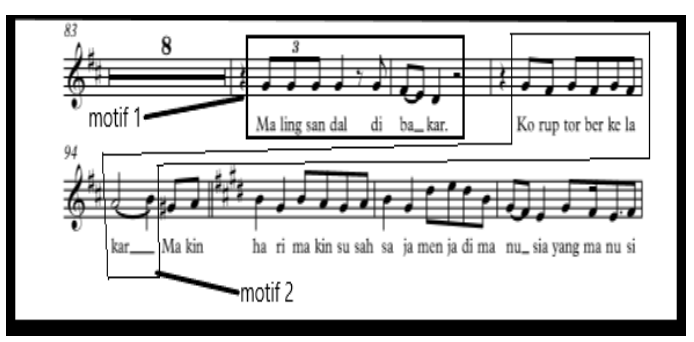

Figure 5. Motif part C 


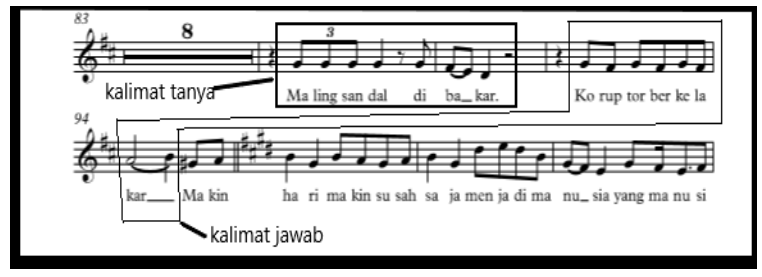

Figure 6. Phrase part C

From the notation of motifs and phrases in part $C$, it can be explained that the first motif (m1) in the second part starts at bar 91 in the second beat to bar 92 in the second beat, the second motif ( $\mathrm{m} 2)$ in the second part of this song is located at bar 93 in the second beat. up to bar 94 in the third beat. The question phrase (c) in this second part is located at bar 91 in the second beat to bar 92 in the second beat, while the answer phrase ( $\mathrm{z}$ ) is located at bar 93 in the second beat to bar 94 in the third beat.

\section{Melody and Interval From Bingung Song}

According to Jamalus (1988: 16) which states that the melody is an arrangement of a series of tones (sounds with regular vibrations) that sound sequentially and rhythmically and express their ideas. Complementing Jamalus's understanding, there is another understanding according to E., (1987: 104) that the melody is a series of notes that are arranged rhythmically with a set height of each. According to Joseph (2001: 68) which explains that the interval is the distance between one pitch and another. The interval is always limited by two pitches. The first pitch is called the base pitch while the second is called the interval pitch. So it can be concluded that the melody is the movement of successive notes that have a certain distance or interval.
1. Song Interval Part A

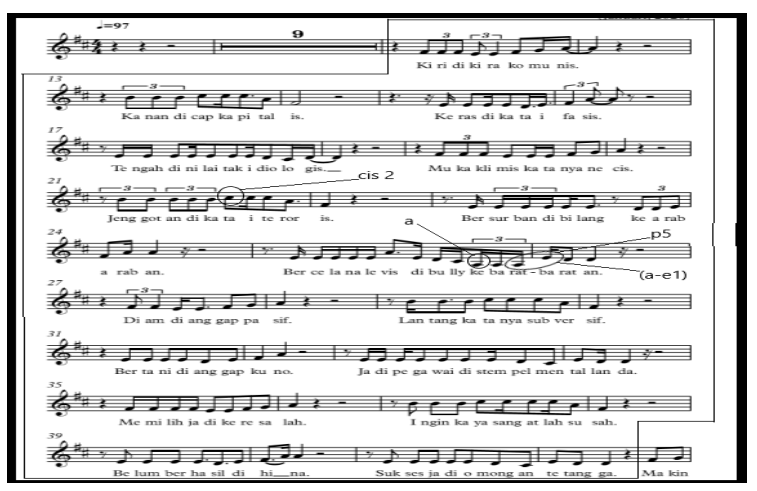

Figure 7. Interval Part A

In part $\mathrm{A}$, judging from the notation above, the lowest note is a tone and the highest note is cis 2. The furthest interval in part A is perfect 5 , from tone a to 1 .

\section{Song Interval Part B}

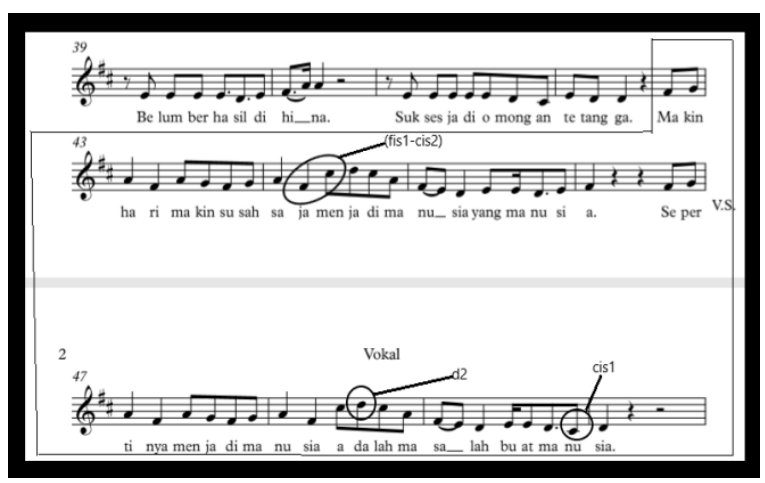

Figure 8. Interval Part B

In part $B$, it can be seen that the ambitus is from cis 1 to $\mathrm{d} 2$. The furthest interval in part $\mathrm{B}$ is from fis1 to cis2. 


\section{Song Interval part C}

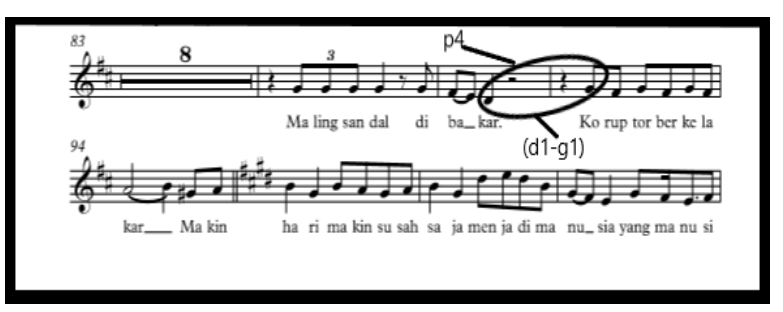

Figure 9. Interval part C

In part $C$, it can be seen that the ambitus is from notes $\mathrm{d} 1$ to $\mathrm{b} 1$. The interval in this part of $\mathrm{C}$ is perfect 4 , which is from note $\mathrm{d} 1$ to tone g1.

\section{Harmonization or Chord Progression Bingung Song}

According to Miller (2017: 39) harmony is a musical element based on the simultaneous merging of tones. If melody is a horizontal concept, harmony is a vertical concept. Complementing the previous statement according to Rochaeni (1989: 34) defines harmony as a combination of various tones that are sounded in unison or arpeggios (sequentially) or the high and low notes are not the same but sound in harmony and are a unanimous unity.

According to Miller (2017: 39) chords are a group of three or more notes that sound together. Not only are chords constructed in a vast variety of variations, but they also move from one to another according to many different patterns. The scheme that shows chord changes is called chord progression. Miller (2017: 42).

\section{Lyrics of Bingung song}

Through song lyrics, songwriters try to express aesthetic ideas. This is because the lyrics of the song are written in such a way that the listener feels entertained and tries to understand the content of the song. In addition, lyrics can also function as a medium of information. That is, song lyrics provide information to the public or listeners about a problem.

Like Iksan Skuter, during an interview, Iksan said that every song he composes starts from what he sees, feels, and Iksan always tries to capture and record social phenomena. The birth of the song Bingung was certainly no exception from the existence of a social phenomenon that was captured by Iksan. There are several phenomena that Iksan caught in the background for the creation of the song Bingung, such as, 1) in 2016 Iksan felt that Indonesian society was in a political phase that clashed two ideologies. 2) there is an allusion to iksan. 3) in 2016 Iksan had a coffee shop, where with the existence of the shop Iksan met and interacted with his shop visitors more often, from this interaction Iksan caught that at that time he and the coffee shop visitors, some of whom were also Iksan's friends, had a similar confusion, confusion when faced with a choice of a problem.

In the song Bingung, Iksan aims to convey what he sees and what he feels, which in fact does not intend to make the song Bingung into a song of criticism of social, even in fact all the songs that Iksan has created do not depart from his desire to make his songs as social critique. All songs are created just like that starting from what he feels. Iksan thinks that he is a musician or an artist whose only job is to create and convey what he feels through a song, without the intention of patronizing and criticizing. Even though in the end, Iksan's songs are often considered as social criticism songs when circulated in the wider community, and Iksan doesn't mind it.

From the results of the author's interview with Iksan Skuter, the author tries to capture that the lyrics of the song Bingung contain lyrics that contain the expression of Iksan scooter's heart for what Iksan feels like what has been described in the previous paragraph, and in the interview Iksan also said that the song Bingung is a song where personally, he wants to emphasize that to be human, it is 
enough to be human, without having to divide the left and right boxes, up and down, the left blames the right, the right blames the left, the top blames the bottom or the bottom blames the top. In this song, Iksan seems to want to convey his disgust with what the media image of him, such as where he is often said to be a leftist musician who sells poverty. Confused seems to represent Iksan Skuter's creative spirit in his lyrics, regardless of how he encounters a life that is increasingly alienated for him. Aesthetically, the lyrics of the song Bingung are straightforward. Not too thick and dense, but enough to accommodate Iksan's taste, taste, and intention.

Finally, for the area of content or semantic messages, Iksan's lyrics talk about various things, but more than half of them do put forward conscious social and political content. Bingung is then dominated by the words of protest against the reality of politics, the state, and the rulers. Iksan tries to represent the voices of the people who are oppressed by certain systems with a solider approach and are more in favor of grassroots understanding, not fragrant issues such as gender, global warming, or American politics (Skuter, 2019:24).

\section{CONCLUSION}

Based on the results of the study, it can be concluded that

(1) the song Bingung consists of three parts, namely part $A$, part $B$, and part $C$ with a sentence structure or musical phrase part $\mathrm{A}$ $(\mathrm{a}, \mathrm{x}), \mathrm{B}(\mathrm{b}, \mathrm{b} 1)$ and $\mathrm{C}(\mathrm{c}, \mathrm{z})$ is a bridge $(2)$ Bingung has a D Major scale with a sound range from a to e 2. (3) uses a chord progression that starts from $\mathrm{D}$ major or the I chord level and ends at the I chord as well. (4) In the song Bingung, there is a modulation which initially uses the basic tone $d o=D$ and then gets modulated to $\mathrm{do}=\mathrm{E}$.

Bingung in the process of its creation from Iksan's desire to convey what Iksan saw, heard and felt. Bingung is a song that was created starting with writing the lyrics first, then making the melody and harmony. There are two versions of the confused song, the first is the band version and the second is the acoustic version. In this study, researchers focused on examining the acoustic version. Acoustic presentation is a form of presentation that makes much more widely known to the public and in his performances, Iksan often performs with the acoustic version.

\section{REFERENCES}

E., S. L. (1987). Komponis, Pemain Musik. In Pustaka Jaya. Jakarta: Pustaka Jaya.

Hardjana, S. (2003). MUSIK KONTEMPORER Dulu dan Kini. Jakarta: Masyarakat Seni Pertunjukan Indonesia.

Iswantara, N. (2016). Kritik Seni Seni Kritik. Semarang: Gigih Pustaka Mandiri.

Jamalus. (1988a). Pengajaran Musik Melalui Pengalaman Musik. Jakarta. Depdikbud.

Jamalus. (1988b). Pengajaran Musik Melalui Pengalaman Musik. Jakarta: Dirjen Dikti Depdikbud.

Joseph, W. (2001). Teori Musik Dasar. In Semarang: Sendratasik. Semarang.

Margono, S. 2003. Metodologi Penelitian Pendidikan. .Jakarta: Rineka Cipta

Muttaqin, M. (2008). Seni Musik Klasik Jilid 1. In Jakarta: Direktorat Pembinaan Sekolah Menengah Kejuruan. (Jilid I). Jakarta: Jakarta: Direktorat Pembinaan Sekolah Menengah Kejuruan.

Ricoeur, P. (2006). Hermeneutika Ilmu Sosial. Yogyakarta: Kreasi Wacana.

Rochaeni. (1989). Seni Musik III. In Ganisa 
Exact. Bandung: Ganisa Exact.

SJ, K.-E. P. (1996). Ilmu Bentuk Musik. In Pusat Musik Liturgi. Pusat Musik Litugi.

Skuter, I. (2019). BINGUNG Antologi Lirik. Yogyakarta: Warning books.

Walzer, M. (2002). The Company Of Critics : Social Criticism and The Twentieth Century. New York Basic Books. 